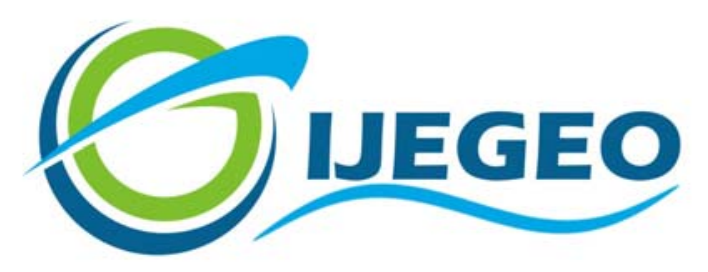

International Journal of Environment and Geoinformatics (IJEGEO) is an international, multidisciplinary, peer reviewed, open access journal.

\title{
An Evaluation of Vanadium Enrichment in the Eastern Shelf Sediments of the Turkish Black Sea
}

\author{
Selma Ünlü, Bedri Alpar \\ Editors
}

Prof. Dr. Cem Gazioğlu, Prof. Dr. Dursun Zafer Şeker, Prof. Dr. Ayşegül Tanık, Assoc. Prof. Dr. Şinasi Kaya

\section{Scientific Committee}

Assoc. Prof. Dr. Hasan Abdullah (BL), Assist. Prof. Dr. Alias Abdulrahman (MAL), Assist. Prof. Dr. Abdullah Aksu, (TR); Prof. Dr. Hasan Atar (TR), Prof. Dr. Lale Balas (TR), Prof. Dr. Levent Bat (TR), Assoc. Prof. Dr. Füsun Balık Şanlı (TR), Prof. Dr. Nuray Balkıs Çağlar (TR), Prof. Dr. Bülent Bayram (TR), Prof. Dr. Şükrü T. Beşiktepe (TR), Dr. Luminita Buga (RO); Prof. Dr. Z. Selmin Burak (TR), Assoc. Prof. Dr. Gürcan Büyüksalih (TR), Dr. Jadunandan Dash (UK), Assist. Prof. Dr. Volkan Demir (TR), Assoc. Prof. Dr. Hande Demirel (TR), Assoc. Prof. Dr. Nazlı Demirel (TR), Dr. Arta Dilo (NL), Prof. Dr. A. Evren Erginal (TR), Dr. Alessandra Giorgetti (IT); Assoc. Prof. Dr. Murat Gündüz (TR), Prof. Dr. Abdulaziz Güneroğlu (TR); Assoc. Prof. Dr. Kensuke Kawamura (JAPAN), Dr. Manik H. Kalubarme (INDIA); Prof. Dr. Fatmagül Kılıç (TR), Prof. Dr. Ufuk Kocabaş (TR), Prof. Dr. Hakan Kutoğlu (TR), Prof. Dr. Nebiye Musaoğlu (TR), Prof. Dr. Erhan Mutlu (TR), Assist. Prof. Dr. Hakan Öniz (TR), Assoc. Prof. Dr. Hasan Özdemir (TR), Prof. Dr. Haluk Özener (TR); Assoc. Prof. Dr. Barış Salihoğlu (TR), Prof. Dr. Elif Sertel (TR), Prof. Dr. Murat Sezgin (TR), Prof. Dr. Nüket Sivri (TR), Assoc. Prof. Dr. Uğur Şanlı (TR), Assoc. Prof. Dr. Seyfettin Taş (TR), Assoc. Prof. Dr. İ. Noyan Yılmaz (TR), Assist. Prof. Dr. Baki Yokeş (TR), Assist. Prof. Dr. Sibel Zeki (TR), Dr. Hakan Kaya (TR). 


\title{
An Evaluation of Vanadium Enrichment in the Eastern Shelf Sediments of the Turkish Black Sea
}

\author{
Selma Ünlü̈ ${ }^{1, *}$ and Bedri Alpar ${ }^{2}$ \\ ${ }^{1}$ İstanbul University, Institute of Marine Sciences and Management, Department of Marine Biology and Physical \\ Oceanography, 34134 Vefa Fatih Istanbul,TR \\ 2 İstanbul University, Institute of Marine Sciences and Management, Department of Marine Geology and Geophysics 34134 \\ Vefa Fatih Istanbul,TR \\ *Corresponding author \\ $\begin{array}{lll}\text { Tel } \quad:+902124400000 & \text { Received: } 28 \text { April } 2017\end{array}$ \\ E-mail : su@istanbul.edu.tr $\quad$ Accepted: 15 May 2017
}

\begin{abstract}
This paper presents an evaluation of the spatial distribution of vanadium level, its enrichment and possible sources in the bottom sediment along the shelf of the Turkish Black Sea. In April 2006, vanadium concentrations were measured along the measurement profiles $(20,50$ and $100 \mathrm{~m})$ using ICP-MS. The vanadium levels ranged from 40 to $315 \mu \mathrm{g} \mathrm{g}^{-1}$, usually within the range of typical and background values $(C f<1)$, except the one offshore the Yeșilırmak River $\left(315.2 \mu \mathrm{g} \mathrm{g}^{-1}\right)$, revealing significant riverine inputs and geographical conditions $(C f>3)$. The concentrations decrease gradually with water depth, implying the dominance of anthropogenic sources such as industrial wastes, agricultural effluents, sewage discharge, and port activities. The vanadium levels had not significant correlations with the physicochemical parameters (sediment texture, water content, TOC) and TPH level in the sediment. At the eastern basin, a serious vanadium enrichment $(\mathrm{Cf}>6-9)$ was observed in November 2010, implying some important regional and seasonal contributions; which may be natural or anthropogenic. Biogeochemical processes, eutrophication, wave-based erosion, abnormal current circulations, bottom morphology and influence of other substances in the environment may be other regulating factors to this enrichment. Continuous monitoring and further studies are required for a detailed description of vanadium mobility and for assessment of the main controlling processes associated with vanadium enrichment in the eastern Black Sea basin.
\end{abstract}

Keywords: Vanadium, Petroleum Hydrocarbon, Marine Sediment, Contamination Factor, Black Sea

\section{Introduction}

Vanadium $(\mathrm{V})$ is a transition metal and one of the lightest members of the first row transition elements. It is a relatively abundant element in the earth's crust $(0.019 \%)$, ranking $22^{\text {nd }}$ in abundance with a mean concentration $150 \quad \mathrm{mg} \mathrm{kg}^{-1} \quad$ (Rehder, 2008). Clay may contain appreciable amounts of vanadium $\left(>200 \mathrm{mg} \mathrm{kg}{ }^{-1}\right)$. The transportation and partitioning of vanadium is influenced by the presence of particulate matter (Moore, 1991). Vanadium is an essential nutrient in trace amounts, but toxic when concentrations increased (Tomlison et al., 1994). Although the amounts of vanadium used are small, combustion of fossil fuels, coal and waste, steel alloy productions, insecticides, dumping of sewage sludge, discharge of domestic wastewater and vessels make significant contributions to environmental contamination (Wann and Jiang, 1997).
The enrichment of vanadium in bottom sediments depends on oil contamination, as well as its biodegradation (Ramondetta and Harris, 1976).

The Black Sea, the largest natural anoxic water basin in the world, is ranked among the most ecologically threatened water bodies (Yüce and Gazioğlu, 2006). It has a surface area of more than 436,000 square kilometers, 5 times larger than its drainage area (Ross and Degens, 1974; Zaitsev et al., 1997). It has a large river system, providing the main part of freshwater, sediment and pollutants. The annual sediment load of Turkish rivers is 28 million tons; corresponding to $20 \%$ of the total (Hay, 1994). The highest annual discharges of the rivers of Yeşilırmak, Kizılırmak, Sakarya and Filyos are 10.3, 7.4, 6.0 and $3.2 \mathrm{~km}^{3}$, respectively (Algan, et al., 1999, 2000; Atlas and Büyükgüngör, 2007). The maximum depth of the Black Sea is more than $2212 \mathrm{~m}$, with an average of $1250 \mathrm{~m}$. 
The water exchange with other seas is small and occurs only along the shallow Turkish Straits. Below 100-150 m water depth, high concentrations of hydrogen sulphide and sulphate-reducing bacteria make this intercontinental sea virtually dead (Murray et al., 1991).

In April 2006, vanadium concentrations have been measured in the shelf sediments recovered from the Turkish Black Sea. The concentrations were within the toxicity limits except a nearshore station at the mouth of the Yeşilirmak River. Although these were the first vanadium data measured along the Turkish Black Sea shelf, they were not published anywhere as the background results, except the elevated concentrations observed on a three-station transect offshore the Yeşilırmak River delta (Ünlü and Alpar, 2009).

Recently, Sur et al. (2012) published a research paper about the enrichment and distribution of some selected metals ( $\mathrm{Al}, \mathrm{Cd}, \mathrm{Cu}, \mathrm{Pb}, \mathrm{Hg}$ and $\mathrm{V})$, using the sediment samples recovered in November 2010. Most of their sampling sediments were taken exactly from the same near-shore stations (20 m water depth) used in this study. The authors reported that the contamination factor $\mathrm{C} f$ for vanadium was bigger than 6 for the most of the eastern stations; Yeşilırmak $>$ Çayeli $>$ Hopa $>$
Yeşilırmak-SK1 > Ordu > Yeşilırmak-SK2 > Akçaabat $>$ Trabzon $>$ Pazar.

Therefore, in addition to present the vanadium levels and spatial distribution along the Turkish Black Sea shelf, the main scopes of this study are to explain anomalous differences between the surveys carried out in April 2006 and November 2010, to determine their correlations with physicochemical parameters and $\mathrm{TPH}$, and finally to assess ecological risk due to sediment contamination.

\section{Materials and Methods Sampling procedure}

In April 2006, the sea bottom sediment samples were recovered from some selected transects, perpendicular to coast (20, 50 and $100 \mathrm{~m}$ water depth) along the Turkish Black Sea shelf, using a grab sampler (Figure 1). The water depths at the stations were between 9 and $103 \mathrm{~m}$. The topmost $3 \mathrm{~cm}$ parts of the grab samples were removed carefully using clean stainless steel spatula. Samples were frozen until analysis at the laboratory. The sediment samples for vanadium analysis were dried and kept in plastic bags.

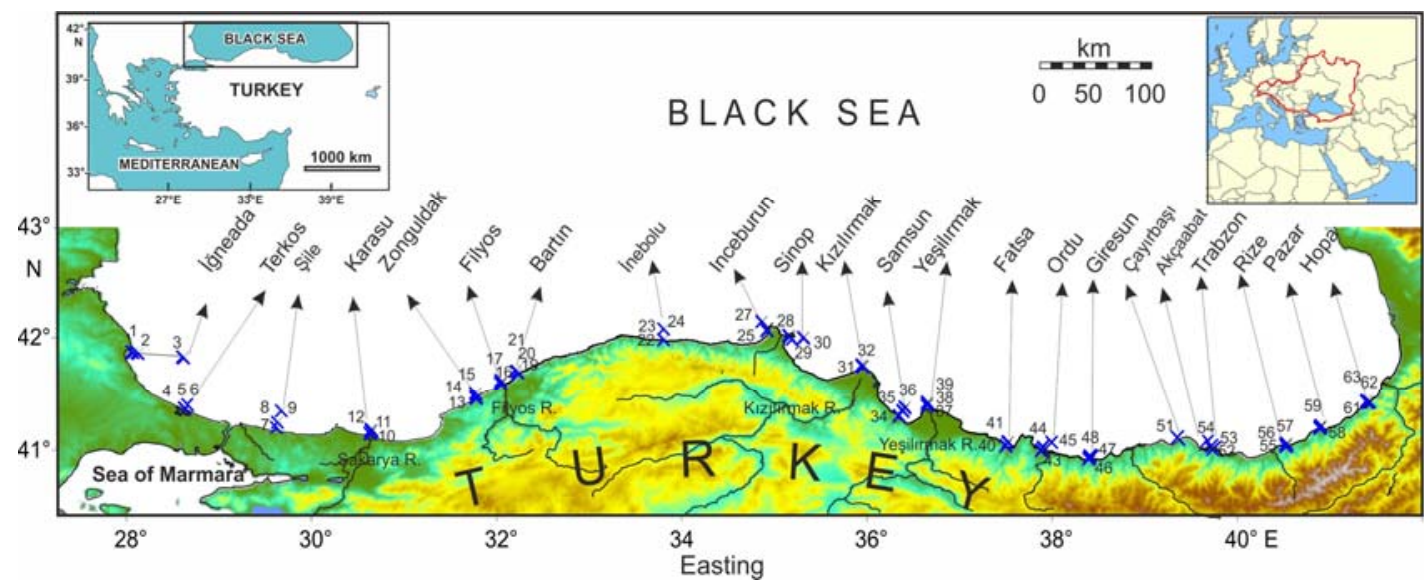

Fig 1. Sediment sampling stations along the Turkish Black Sea shelf. Insets show the study region and the drainage area of the Black Sea basin.

\section{Sample preparation for chemical analysis}

Approximately $10 \mathrm{~g}$ wet weight of sediments was placed in a labeled precombusted jar for chemical drying with anhydrous sodium sulfate until the sample was dry, free-flowing, and homogeneous, then automatic Soxhlet-extracted with dichloromethane $(100 \mathrm{ml})$ for $8 \mathrm{~h}$ with activated copper. Two grams of anhydrous sodium sulfate were added to remove water. 
The combined extracts were dried with anhydrous sodium sulphate, and the volume was reduced to $2 \mathrm{ml}$ by rotary evaporation.

The samples were also prepared for textural analyses, moisture content, total organic carbon (TOC) and total petroleum hydrocarbon (TPH).

\section{Vanadium Analyses}

The vanadium concentrations in samples were determined using ICP-MS (Thermo Elemental X7) at MERLAB Central Research Laboratory of Istanbul University, and validated according to polluted marine sediment IAEA Soil 7 and IAEA 405 reference materials. Each sample was measured in triplicate; mean, standard deviation and percentage of relative standard deviations (RSD\%) were calculated (Table 1). Performance and validation parameters of the analytical methodology for analysis of vanadium are summarized in Table 1. The precision of the results were evaluated by percentage relative standard deviation of the results of three samples. In this study, the values of relative standard deviation and the average recoveries were lower than $2 \%$ and $98-101 \%$, respectively.

\section{Other analyses in the sediment samples}

The changes in the particle grain size (PGS) fractions can influence the chemical compositions of the sediments significantly. Mud fraction, for example, is the most reactive fraction of the total sediment for hydrocarbon adsorption and/or organic-inorganic complex formation (Romankevich, 1984). PGS analysis is broken down into several steps dealing first with the coarse fraction (sand and gravel) and then with the fine fraction (silt and clay). It was performed using petrographic procedures described by GERG SOP-8908.

The total organic carbon content of sediment samples were measured by a Thermo Finnigan FLASH EA 1112 model CHN analyzer at the Advanced Analyses Laboratories, Istanbul, after removing the inorganic carbonate fractions, and were replicated within runs and over time with a confidence interval of $0.1 \%$. TOC were measured by means of the WalkleyBlack method (Loring and Rantala, 1992). The analytical precision of analysis was better than $\pm 4 \%$ at $95 \%$ significance level from five replicates.

The total concentration of petroleum hydrocarbons in the extracts measure using a luminescence spectrometer (Jasco-6300 Shimadzu) and were given in detail by Ünlü et al. (2009).

\section{Statistical Analyses}

Pearson's correlation coefficients calculated the strength of relationships between the vanadium and TPH concentrations, and principal component analysis (PCA) quantified spatial/temporal variability of vanadium sources for Turkish Black Sea coast sediment samples. The first few components explain the inherent variances to largest possible extent (Varmuza and Filzmoser, 2008). In the present study, PCA was conducted with varimax rotation. The first three eigenvalues retained were greater than one; as 2.1, 1.2 and 1.0 $(\mathrm{n}=55)$.

\section{Results}

\section{Textural characteristics of sediment}

The southern shelves of the Black Sea extend northwards until a shelf break at about 100-130 $\mathrm{m}$ water depth. The sediment samples usually stay within the oxygenated surface layer of the Black Sea, which is $50-100 \mathrm{~m}$ thick (Table 1). They are composed of various size-grained sediments, mud is dominant. Even though the main controlling parameter is depth, the sea floor morphology of the Black Sea intersected with canyons (Algan et al., 2002) and biogeochemical processes in sediment and water column (Inglet et al., 2008; Bat et al., 2015; Bat and Özkan, 2015) are also important on the granulometric distribution of the surface sediments. 
Table 1. Sampling depth, sediment texture (shell, pebble, sand, silt and clay \%), sediment water content (swc \%), organic carbon (TOC\%), concentrations of total petroleum hydrocarbon (TPH) and vanadium ( $\mu \mathrm{g} \mathrm{g}^{-1}$ dry weight) in the sediment samples.

\begin{tabular}{|c|c|c|c|c|c|c|c|c|c|c|c|c|c|}
\hline Region & Station & Depth & Shell & Pebble & Sand & Silt & Clay & swc & TOC & TPH & $\mathrm{V}$ & V-StDev & V-\%RSD \\
\hline \multirow[t]{3}{*}{ Igneada } & S1 & 23 & 27,4 & 0,0 & 99,9 & 0,1 & 0 & 14,4 & 0,5 & 64 & 44,0 & 0,2 & 0,2 \\
\hline & S2 & 50 & 0,0 & 0,5 & 7,4 & 50,6 & 42 & 57,8 & 1,5 & 63 & 95,6 & 0,8 & 0,5 \\
\hline & S3 & 100 & 9,4 & 6,3 & 9,4 & 37,1 & 47 & 47,4 & 2,4 & 17 & 103,8 & 0,1 & 0,0 \\
\hline \multirow[t]{2}{*}{ Terkos } & S4 & 21 & 39,3 & 24,8 & 72,1 & 3,1 & 0,0 & 16,5 & 1,2 & 2 & 40,5 & 0,6 & 0,8 \\
\hline & S6 & 94 & 0,0 & 0,5 & 4,6 & 62,6 & 32,2 & 59,6 & 2,5 & 27 & 53,0 & 0,9 & 1,0 \\
\hline \multirow[t]{3}{*}{ Şile } & S7 & 28 & 0,0 & 16,7 & 80,9 & 1,3 & 1,1 & 21,2 & 1,3 & 33 & 51,6 & 1,0 & 1,1 \\
\hline & S8 & 51 & 47,7 & 37,0 & 45,1 & 7,8 & 10,1 & 27,8 & 1,6 & 13 & 60,1 & 1,1 & 1,0 \\
\hline & S9 & 103 & 22,1 & 18,8 & 30,1 & 23,5 & 27,6 & 36,9 & 1,8 & 6 & 52,2 & 0,8 & 0,8 \\
\hline \multirow[t]{2}{*}{ Karasu } & S10 & 21 & 45,2 & 8,9 & 87,1 & 2,3 & 1,8 & 27,7 & 1,1 & 7 & 99,3 & 0,4 & 0,2 \\
\hline & $\mathrm{S} 12$ & 98 & 0,0 & 0,0 & 0,0 & 52,6 & 47,4 & 59,3 & 2,7 & 14 & 124,9 & 0,7 & 0,3 \\
\hline \multirow[t]{3}{*}{ Zonguldak } & S13 & 23 & 0,0 & 0,0 & 12,7 & 41,6 & 45,6 & 25,7 & 3,2 & 5497 & 111,2 & 0,8 & 0,4 \\
\hline & S14 & 51 & 18,0 & 6,2 & 29,8 & 42,5 & 21,5 & 38,2 & 2,1 & 3939 & 121,3 & 0,5 & 0,2 \\
\hline & S15 & 103 & 0,0 & 12,9 & 27,8 & 34,7 & 24,6 & 43,5 & 1,4 & 257 & 95,4 & 0,2 & 0,1 \\
\hline \multirow[t]{2}{*}{ Filyos } & S16 & 21 & 0,0 & 0,5 & 8,2 & 67,7 & 23,6 & 21,3 & 1 & 53 & 104,5 & 0,4 & 0,2 \\
\hline & S17 & 50 & 20,5 & 10,6 & 3,9 & 62,1 & 23,5 & 36,0 & 2,1 & 205 & 98,6 & 0,8 & 0,5 \\
\hline \multirow[t]{3}{*}{ Bartın } & $\mathrm{S} 19$ & 21 & 0,0 & 1,7 & 54,3 & 28,1 & 15,9 & 29,5 & 0,7 & 121 & 87,2 & 0,6 & 0,4 \\
\hline & S20 & 54 & 0,0 & 2,1 & 5,5 & 50,7 & 41,8 & 40,5 & 1,2 & 143 & 106,0 & 1,2 & 0,6 \\
\hline & S21 & 103 & 0,0 & 0,0 & 0,0 & 56,7 & 43,3 & 45,1 & 1,3 & 220 & 117,5 & 1,4 & 0,9 \\
\hline \multirow[t]{3}{*}{ Inebolu } & S22 & 23 & 63,4 & 4,4 & 62,9 & 25,3 & 7,3 & 26,7 & 0,5 & 27 & 64,3 & 0,9 & 0,8 \\
\hline & S23 & 48 & 12,7 & 0,1 & 21,0 & 53,0 & 26,0 & 51,7 & 1,2 & 18 & 66,4 & 0,9 & 0,7 \\
\hline & S24 & 100 & 6,4 & 0,8 & 4,9 & 53,5 & 40,8 & 51,9 & 1,7 & 41 & 80,0 & 0,2 & 0,1 \\
\hline \multirow[t]{2}{*}{ Inceburun } & S25 & 21 & 12,7 & 0,0 & 98,1 & 1,9 & 0,0 & 20,1 & 0,8 & 8 & 59,2 & 0,6 & 0,6 \\
\hline & S27 & 101 & 23,5 & 0,0 & 30,4 & 35,4 & 34,2 & 46,9 & 1,5 & 25 & 114,6 & 0,9 & 0,4 \\
\hline \multirow[t]{3}{*}{ Sinop } & $\mathrm{S} 28$ & 21 & 28,9 & 26,4 & 37,4 & 18,7 & 17,5 & 32,7 & 1 & 321 & 101,6 & 1,6 & 0,9 \\
\hline & S29 & 49 & 2,4 & 1,5 & 0,9 & 47,4 & 50,2 & 53,8 & 1,6 & 18 & 136,5 & 0,8 & 0,3 \\
\hline & $\mathrm{S} 30$ & 97 & 19,4 & 4,7 & 14,4 & 45,3 & 35,7 & 43,9 & 1,6 & 21 & 110,2 & 0,6 & 0,3 \\
\hline \multirow[t]{3}{*}{ Kızılırmak } & S31 & 25 & 0,8 & 0,0 & 1,5 & 67,8 & 30,7 & 32,1 & 0,7 & 9 & 111,0 & 1,4 & 0,7 \\
\hline & S32 & 38 & 0,0 & 0,3 & 13,9 & 65,4 & 20,5 & 37,1 & 0,8 & 37 & 113,5 & 1,5 & 0,8 \\
\hline & S33 & 103 & 2,5 & 0,0 & 3,2 & 62,4 & 34,4 & 45,0 & 1,3 & 23 & 79,1 & 0,7 & 0,5 \\
\hline \multirow[t]{3}{*}{ Samsun } & S34 & 13 & 0,0 & 0,0 & 1,4 & 54,1 & 44,5 & 8,9 & 2 & 297 & 129,3 & 1,2 & 0,5 \\
\hline & S35 & 51 & 0,0 & 0,0 & 0,0 & 54,6 & 45,4 & 46,1 & 0,9 & 18 & 119,0 & 0,7 & 0,3 \\
\hline & S36 & 103 & 11,5 & 1,3 & 7,4 & 45,9 & 45,5 & 50,4 & 1,7 & 25 & 125,7 & 1,3 & 0,6 \\
\hline \multirow[t]{3}{*}{ Yeşilırmak } & S37 & 12 & 46,0 & 0,0 & 98,2 & 0,8 & 1,0 & 17,3 & 0,8 & 5 & 315,2 & 1,4 & 0,3 \\
\hline & S38 & 51 & 5,6 & 2,4 & 5,0 & 55,6 & 37,0 & 46,1 & 1,3 & 6 & 151,2 & 1,4 & 0,5 \\
\hline & S39 & 103 & 0,0 & 0,0 & 3,5 & 42,5 & 53,9 & 47,3 & 1,3 & 25 & 127,3 & 1,8 & 0,8 \\
\hline Fatsa & $\mathrm{S} 40$ & 21 & 0,0 & 0,0 & 36,3 & 29,1 & 34,5 & 43,1 & 0,7 & 22 & 151,1 & 1,0 & 0,4 \\
\hline & S41 & 51 & 0,0 & 0,5 & 4,0 & 62,3 & 33,2 & 44,3 & 1,6 & 45 & 148,3 & 0,5 & 0,2 \\
\hline Ordu & S43 & 9 & 45,3 & 1,7 & 55,7 & 35,8 & 6,9 & 23,7 & 0,7 & 8 & 141,5 & 2,0 & 0,8 \\
\hline & S44 & 53 & 0,0 & 3,7 & 3,4 & 60,9 & 32,0 & 45,2 & 3,2 & 52 & 140,2 & 1,0 & 0,4 \\
\hline & S45 & 100 & 8,2 & 3,3 & 6,6 & 41,6 & 48,5 & 55,5 & 1,9 & 13 & 134,9 & 1,9 & 0,8 \\
\hline Giresun & S46 & 21 & 14,4 & 20,4 & 79,0 & 0,7 & 0,0 & 20,8 & 0,7 & 471 & 104,8 & 0,7 & 0,4 \\
\hline & S47 & 53 & 8,9 & 2,3 & 12,8 & 64,8 & 20,1 & 48,1 & 1,7 & 37 & 133,5 & 1,2 & 0,5 \\
\hline & S48 & 98 & 10,0 & 0,7 & 24,2 & 51,0 & 24,1 & 44,8 & 2,1 & 9 & 130,1 & 0,3 & 0,1 \\
\hline Çarşıbaşı & S51 & 95 & 11,8 & 0,4 & 37,2 & 41,3 & 21,1 & 53,8 & 1,2 & 36 & 71,4 & 0,0 & 0,0 \\
\hline Trabzon & S52 & 10 & 0,0 & 0,0 & 6,5 & 70,7 & 22,9 & 38,4 & 0,9 & 52 & 119,0 & 0,8 & 0,4 \\
\hline & S53 & 52 & 0,0 & 0,2 & 9,8 & 58,5 & 31,5 & 50,6 & 1,7 & 65 & 110,3 & 0,5 & 0,3 \\
\hline Akçaabat & S54 & 93 & 3,8 & 1,5 & 11,4 & 54,6 & 32,5 & 40,8 & 1,4 & 33 & 120,5 & 0,8 & 0,4 \\
\hline Rize & S55 & 21 & 1,6 & 0,0 & 71,1 & 25,3 & 3,6 & 28,8 & 1,1 & 48 & 111,8 & 2,4 & 1,2 \\
\hline & S56 & 53 & 0,0 & 0,2 & 12,2 & 69,0 & 18,5 & 53,2 & 2,1 & 49 & 116,3 & 0,8 & 0,4 \\
\hline & S57 & 113 & 0,0 & 0,0 & 2,6 & 70,3 & 27,1 & 48,6 & 1,9 & 41 & 109,9 & 0,4 & 0,2 \\
\hline Pazar & S58 & 21 & 41,9 & 15,8 & 58,9 & 18,2 & 7,1 & 11,5 & 1,4 & 19 & 106,6 & 0,2 & 0,1 \\
\hline & S59 & 52 & 21,1 & 10,8 & 29,6 & 41,0 & 18,5 & 45,8 & 2,4 & 49 & 127,7 & 1,0 & 0,5 \\
\hline Hopa & S61 & 22 & 1,6 & 0,0 & 98,5 & 1,5 & 0,0 & 17,5 & 1,3 & 35 & 141,4 & 0,5 & 0,2 \\
\hline & S62 & 52 & 0,0 & 0,8 & 11,1 & 65,4 & 22,7 & 47,4 & 2,6 & 38 & 133,6 & 0,7 & 0,3 \\
\hline & $\mathrm{S} 63$ & 101 & 0,0 & 1,5 & 19,2 & 55,9 & 23,4 & 47,4 & 2,3 & 853 & 131,0 & 0,4 & 0,2 \\
\hline & $\mathrm{MIN}$ & 9,0 & 0,0 & 0,0 & 0,0 & 0,1 & 0,0 & 8,9 & 0,5 & 2 & 40,5 & 0,0 & 0,0 \\
\hline & MAX & 113,0 & 63,4 & 37,0 & 99,9 & 70,7 & 53,9 & 59,6 & 3,2 & 5497 & 315,2 & 2,4 & 1,2 \\
\hline & MEAN & 55,7 & 11,5 & 4,6 & 28,6 & 41,3 & 25,5 & 38,5 & 1,5 & 247 & 110,1 & 0,9 & 0,5 \\
\hline
\end{tabular}




\section{TOC and TPH Distributions}

The TOC content in the sediments ranges from 0.5 to $3.2 \%$ with an average of $1.5 \pm 0.7 \%$ $(n=55)$ (Table 1). The highest values of TOC content were recorded offshore the harbours of Zonguldak and Ordu (3.2\%), possibly due to coal production and port activities.

The levels of total hydrocarbon are scattered in a wide range from 2 to $5497 \mu \mathrm{g} \mathrm{g}^{-1}$ (dry weight) (Table 1). The high values $(>100 \mu \mathrm{g}$ $\mathrm{g}^{-1} \mathrm{dw}$ ) confirm chronic oil pollution, especially those measured near the Zonguldak port (257-5497 $\left.\mu \mathrm{g} \mathrm{g}^{-1}\right)$, Hopa $\left(853 \mu \mathrm{g} \mathrm{g}^{-1}\right)$, Giresun (471 $\left.\mu \mathrm{g} \mathrm{g}^{-1}\right)$, Sinop (321 $\left.\mu \mathrm{g} \mathrm{g}^{-1}\right)$, Samsun (297 $\left.\mu \mathrm{g} \mathrm{g}^{-1}\right)$, Bartın

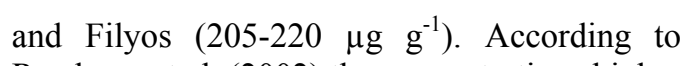
Readman et al. (2002) the concentrations higher than $100 \mu \mathrm{g} \mathrm{g}^{-1} \mathrm{dw}$ are mainly related with port activities or riverine (terrestrial) inputs.

\section{Vanadium levels in sediment samples}

Results indicated that the levels of vanadium in the sediment ranged from 40 to $315 \mu \mathrm{g} \mathrm{g}^{-1}$, with a mean value of $110 \mu \mathrm{g} \mathrm{g}^{-1}$ (Table 1). Almost all of these concentrations are within the range of typical and background values (20- $150 \mu \mathrm{g} \mathrm{g}^{-1}$ ) recorded for sediment by Moore (1991), except S37, which had the extreme value of vanadium $\left(315.2 \mu \mathrm{g} \mathrm{g}^{-1}\right)$.

Table 2. Comparison of vanadium levels in the sediments from the Mediterranean region.

\begin{tabular}{lccl}
\hline Region & Sampling Year & $\mathrm{V}\left(\mu \mathrm{g} \mathrm{g}^{-1}\right)$ & References \\
\hline Near shores, Kuwait & 1995 & $25-179$ & Metwally et al., 1997 \\
Suez Bay, Egypt & 2004 & $4-168$ & El-Moselhy, 2006 \\
Red Sea, Egypt & 2004 & $8-214$ & El-Moselhy, 2006 \\
Western Black Sea,Turkey & 2010 & $10-152$ & Sur et al., 2012 \\
Eastern Black Sea, Turkey & 2010 & $40-1215$ & Sur et al., 2012 \\
Eastern Mediterranean Sea, Egypt & 2008 & $25-575$ & Abdel Ghani et al., 2013 \\
Western Black Sea, Turkey & 2006 & $40-125$ & This study \\
Eastern Black Sea, Turkey & 2006 & $71-315$ & This study \\
\hline
\end{tabular}

The sediment sample S37 was recovered from a water depth of $-12 \mathrm{~m}$ nearshore the Yeşilırmak River delta that receives huge amount of wastewater effluents. Such kind of sediments offshore lowland areas are likely to host the higher amount of vanadium coming from river particulates (McLennan and Murray, 1999). On the other hand, the lowest concentration (40.5 $\mu \mathrm{g} \mathrm{g}^{-1}$ ) was observed at station S4, at the western side and offshore a fresh water lake (Terkos). For an overall assessment, the vanadium concentrations from the survey carried out in April 2006 was in the range of other data recorded from other parts of the Mediterranean region (Table 2).

The samples at the eastern part of the study area have higher vanadium concentrations. In other words, the mean of the stations remained to the east of $34^{\circ} \mathrm{E}\left(126 \pm 39 \mu \mathrm{g} \mathrm{g}^{-1}\right)$ was significantly higher than the mean of western stations $\left(85 \pm 27 \mu \mathrm{g} \mathrm{g}^{-1}\right)$. In the eastern side, the concentration levels also decrease gradually with the depth of water (Figure 2).

\section{Comparison with November 2010 survey data}

In fact, they were the first vanadium data measured systematically along the Turkish Black Sea shelf, and they could only be used as background data for future monitoring. The vanadium levels were low, except the maximum at S37 and the slight elevation of concentrations at the eastern basin. Recently, Sur et al. (2012) published a research paper indicating metal contaminations $(\mathrm{Al}, \mathrm{Cd}, \mathrm{Cu}$, $\mathrm{Pb}, \mathrm{Hg}$ and $\mathrm{V}$ ) along the Black Sea coast; using the sediment samples exactly taken from the same near-shore stations given above. The authors reported that the contamination factor $\mathrm{C} f$ was bigger than 6 for the nearshore stations at Hopa, Ordu, Çayeli, Trabzon, Yeşilırmak, Akçaabat and Pazar (Sur et al., 2012). They found vanadium was enriched very much $(C f>6)$ in most of the eastern stations; Yeşilırmak $>$ Çayeli $>$ Hopa $>$ Yeşilırmak SK1 > Ordu > Yeşilırmak SK2 $>$ Akçaabat $>$ Tabzon $>$ Pazar. 
Ünlü and Alpar., IJEGEO, 4(2) 128-138 (2017)

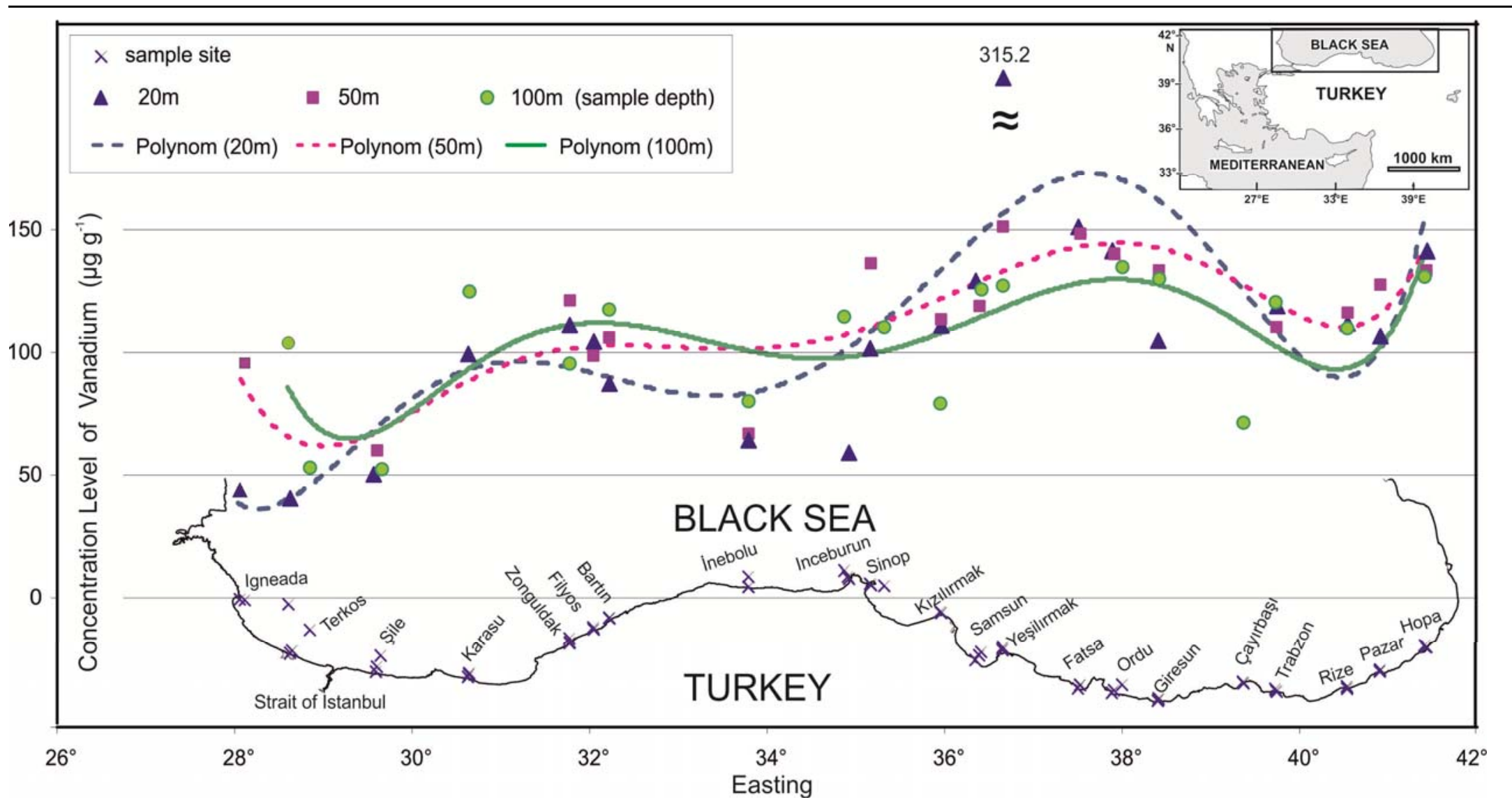

Fig 2. Distribution of vanadium levels in sediment along the narrow Turkish Black Sea shelf. The concentration levels and their polynomial fits for 20,50 and $100 \mathrm{~m}$ water depths are slightly different. 
The contamination factor ( $\mathrm{C} f$, Håkanson, 1980) is a kind of normalization according to a background value. The average crustal abundances (background) of vanadium is 130 $\mu \mathrm{g} \mathrm{g}^{-1}$ for (Turekian and Wedepohl 1961; Taylor 1972). A comparison of $\mathrm{C} f$ data for April 2006 and November 2010 surveys reveal an important enrichment at the eastern basin that must be explained (Figure 3).

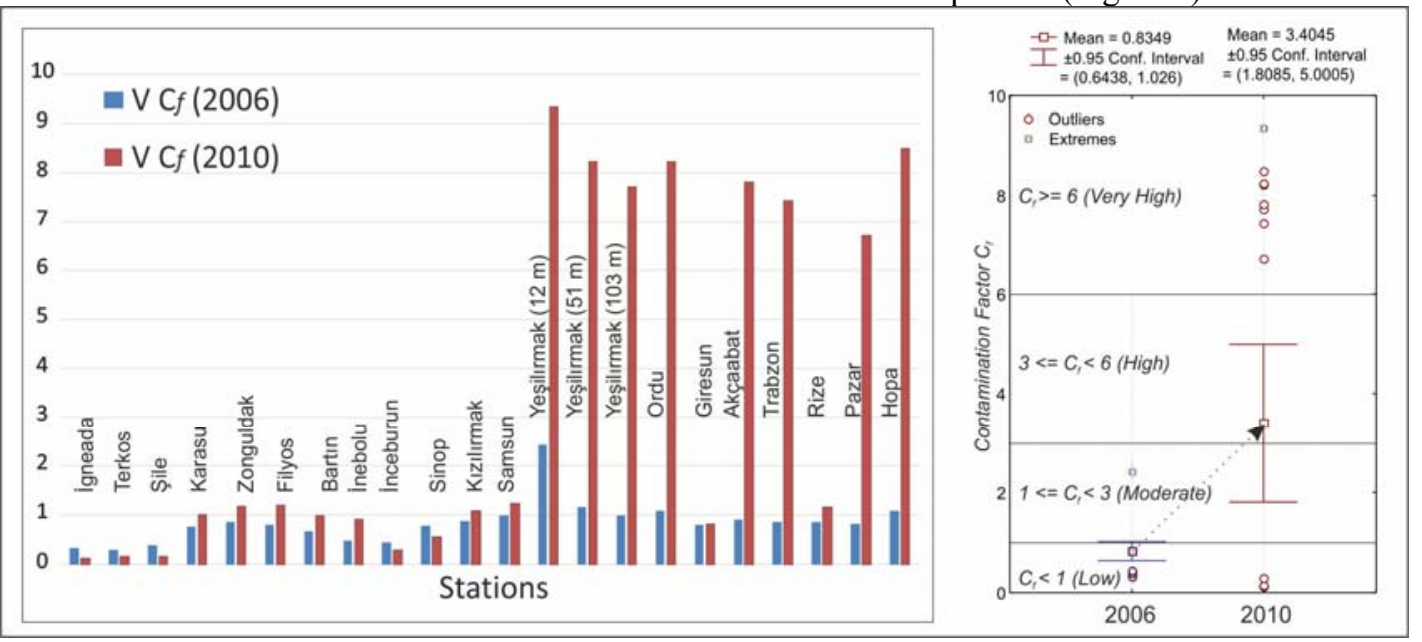

Fig 3. Comparison of contamination factors (Cf) of vanadium levels for 2006 (April) and 2010 (November) surveys and their box and Whisker plots. The $\mathrm{C} f$ values less than unity 1 refer to low contamination, while $1 \leq \mathrm{C} f<3$ means moderate contamination, $3 \leq \mathrm{C} f<6$ considerable contamination, and finally $\mathrm{C} f \geq 6$ indicates very high contamination.

\section{Statistical relationships between parameters}

The regression analysis revealed the relationships between the concentration of vanadium, percentage of grain size, sediment water content, TOC and total petroleum hydrocarbon levels (Table 2). The TOC concentrations increase slightly with the increasing depth and finer grain size (i.e. silt and clay). The finer grained sediments have much ability to carry and store pollutants than coarse-grained sandy sediments. Therefore, the samples with higher TOC values are mostly made up of fine-grained sediments.

The regression analysis shows no significant correlations among the vanadium concentrations, other physicochemical parameters and TPH level (Table 2). Large accidental spills generally cause significant vanadium contamination in sediment. However, there was not any meaningful relationship between the levels of vanadium and TPH for the samples. In that case, the enrichment of vanadium observed at the eastern Black Sea stations may be associated with the reasons given below; a) natural release to sediment because of weathering of rocks,

b) dominant current regime of the eastern basin,

c) wet and dry deposition vanadiumcontaining particulates during combustion of coal and residual fuel oils,

d) transportation of sediment, including mineral matter, chemicals, pollutants and organic matter via the rivers.

\section{Source identification of the vanadium pollution}

Principal component analysis (PCA) is a useful statistical tool to define if relevant relationships exist between the cases. Three principal components were retrieved for the Black Sea shelf sediments (Eigen values $>1$ ). Including the loadings of vanadium, TPH, and the physicochemical parameters, the variance loadings of the first three factors were 44.3, 24.4 and $19.8 \%$ of the total variability respectively (accumulative variance $86.5 \%$, $\mathrm{n}=55$ ). The first two factors used to identify the source categories and the loadings are shown in Figures $4 a$ and $b$. 
Factor 1. Accounting for 42.3 of total variance, this factor exhibits higher loadings for the percentages of mud, sediment water content and TOC.

Factor 2. This factor show $24.4 \%$ of total variance (Figure 4a). This factor predominantly composed by TPH pollution solely, coming from point sources. They were observed at the stations close to the coast; i.e. Zonguldak and Samsun (S13, S14 and S34). At these sampling points, TPH levels were greater than $100 \mu \mathrm{g} \mathrm{g}^{-1}$, implying occurrence of oil spill or leakage pollution caused by vessels, possible discharges from municipal and industrial wastewater or occasional surficial runoff.

Factor 3. The third factor is responsible for $19.8 \%$ of the total variance. This factor exhibits higher loadings of vanadium (Figure $4 \mathrm{~b}$ ). The highest concentration was observed at the station S3 at the mouth of the Yeşilırmak. The positive values of the third factor correspond to the vanadium levels smaller than $90 \mu \mathrm{g} \mathrm{g}^{-1} \mathrm{dw}$.

Table 2. Pearson-coefficient correlation matrix (r) between the concentrations of vanadium and other parameters in the sediment samples $(n=55)$.

\begin{tabular}{lcccccccc}
\hline & Depth & Silt & Clay & Mud & swc & TOC & TPH & V \\
\hline Depth & 1.00 & & & & & & & \\
Silt & $.386^{* *}$ & 1.00 & & & & & & \\
Clay & $.574^{* *}$ & $.540^{* *}$ & 1.00 & & & & & \\
Mud & $.511^{* *}$ & $.936^{*}$ & $.870^{* *}$ & 1.00 & & & & \\
swc & $.714^{* *}$ & $.637^{* *}$ & $.663^{* *}$ & $.713^{* *}$ & 1.00 & & & \\
TOC & $.433^{* *}$ & $.391^{* *}$ & $.428^{* *}$ & $.447^{* *}$ & $.425^{* *}$ & 1.00 & & \\
TPH & -.110 & .008 & .115 & .058 & -.119 & $.373^{* *}$ & 1.00 & \\
V & -.098 & .127 & .134 & .143 & .034 & .070 & .029 & 1.00 \\
\hline
\end{tabular}

** Correlation is significant at the 0.01 level (2-tailed).

\section{Discussion and Conclusion}

The vanadium levels in the sediment of the Turkish Black Sea shelf indicated low range spectra, usually below the background values $\left(20-150 \mu \mathrm{g} \mathrm{g}^{-1}\right)$, except an accumulation (315.2 $\mu \mathrm{g} \mathrm{g}^{-1}$ ) nearshore the Yeşilirmak. This indicated that the subaqueous part of the Yeşilırmak River delta receives significant amount of vanadium from riverine particulates. Sur et al. (2012) suggested that these anomalous accumulations were related with sulfuric acid production in the region. In addition, the vanadium concentrations indicated elevated levels at the eastern margin, implying that geographical variations from both anthropogenic (e.g. riverine inputs, dumping of sewage sludge, discharge of domestic wastewater and atmospheric emissions) and natural sources (e.g. mineralogical backgrounds, eutrophication under anaerobic conditions, bioturbation and organic-rich shales) were important. In general, the levels decrease with water depth gradually, possibly due to decreasing effects of industrial discharges, other terrestrial inputs and natural weathering processes. 

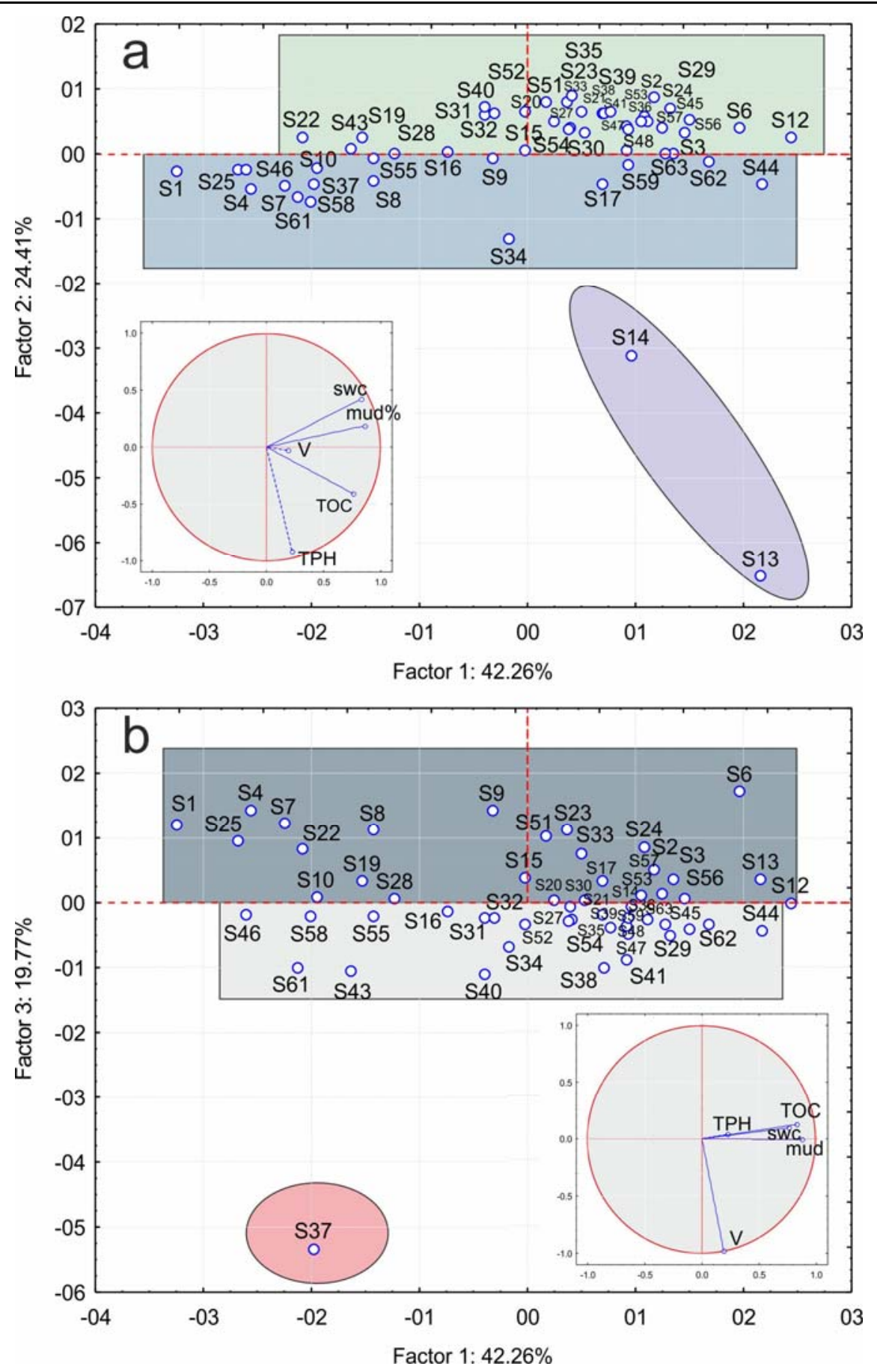

Fig 4. The projection of the variables and cases on the factor plains of a) $1 \times 2$ and b) $1 \times 3$ for the Turkish Black Sea shelf sediments.

Anomalous increment of vanadium concentrations was observed at the eastern basin sediment recovered in November 2010. A six-to-nine times increment of $\mathrm{C} f$ index indicates that vanadium has been elevated due to some seasonal influences of the Turkish rivers or primary production of organic matter. The counterclockwise gyres and longshore currents, partly controlled by the sea bottom morphology, and wave-based erosion caused by 
waves may have been contributed to this enrichment as well. Moreover, the concentration levels may become variable under the control of various substances (e.g. fulvic and humic acids) presented in the environment.

Several planned and continuous monitoring studies are needed such as a) to explain of vanadium variations in sediment and its mobility, b) to determine the correlations between vanadium and organic matters, c) to define exchange of vanadium between sediment and seawater with direct flux measurements, etc. Similar studies will provide a basis for environmental impact assessment and control.

\section{Acknowledgements}

The sediment samples were collected within the framework of pollution monitoring project supported by the Republic of Turkey Ministry of Environment and Urbanization. The authors owe gratitude to the staff of the retired $R / V$ ARAR of the Istanbul University. The financial supports for the laboratory analyses were provided by the Research Fund of Istanbul University under the projects of YÖP 26219 and BEK-21558.

\section{References}

Abdel Ghani, S.A., Shobier, A.H. Shreadah, M.A. (2013). Assessment of arsenic and vanadium pollution in surface sediments of the Egyptian Mediterranean coast. International Journal of Environmental Technology and Management, 16(1/2), 82101.

Algan O, Gazioğlu C, Çağatay N, Yücel ZY., Gönençgil B. (1999). Sediment and water influxes into the Black Sea by Anatolian rivers. Zeitschrift für Geomorphologie 43,61-79.

Algan O., Gazioğlu C., Yücel Z., Çağatay N., Gönençgil B. (2000). Sediment and Freshwater Discharges of the Anatolian River into the Black Sea, IOC-BSRC Workshop «Black Sea Fluxes», Workshop Report No. 145. Paris: UNESCO, 38-50.

Algan, O., Gökaşan, E., Gazioğlu, C., Yücel, Z Alpar, B., Güneysu, C., Kırcı, E.,
Demirel, S., Sarı, E., Ongan, D. (2002). A high resolution seismic study in Sakarya

Delta and Submarine canyon, southern Black Sea. Continental Shelf Research, 22(10), 1511-1527.

Atlas, L. and Büyükgüngör, H. (2007). Heavy metal pollution in the Black Sea shore and offshore of Turkey. Environmental Geology, 52, 469-476.

Bat, L. and Özkan, E.Y. (2015). Chapter 13. Heavy metal levels in sediment of the Turkish Black Sea coast. In: Bikarska I, Raykov V, Nikolov N. (Eds.) Progressive Engineering Practices in Marine Resource Management. IGI Global book series Advances in Environmental Engineering and Green Technologies (AEEGT) (ISSN: 2326-9162; eISSN: 2326-9170) USA, pp. $399-419$.

Bat, L., Özkan E.Y. and Öztekin, H.C. (2015). The contamination status of trace metals in Sinop coast of the Black Sea, Turkey. Caspian Journal of Environmental Sciences, 13 (1), 1-10.

El-Moselhy, Kh. M. (2006). Distribution of vanadium in bottom sediments from the marine coastal area of the Egyptian Seas. Egyptian Journal of Aquatic Research, 32(1), 12-21.

Håkanson, L. (1980). An ecological risk index for aquatic pollution control: A sedimentological approach. Water Research, 14, 975-1001.

Hay, B. J. (1994). Sediment and water discharge rates of Turkish Black Sea rivers before and after hydropower dam construction. Environmental Geology, 23, 276-283.

Inglett, P.W., Inglett, K.S. and Reddy, K.R. (2008). Biogeochemical processes and implications for nutrient cycling. In: Brown, M.T., Reiss, K.C., Cohen, M.J., Evans, J.M., Inglett, P.W., Inglett, K.S., Reddy, K.R., Frazer, T.K., Jacoby, C.A., Phlips, E.J., Knight, R,L., Notestein, S.K., Hamann, R.G., McKee, K.A. (Eds.), Summary and Synthesis of the Available Literature on the Effects of Nutrients on Spring Organisms and Systems. University of Florida Water Institute, 570 Weil Hall, Gainesville, FL 32611-6601. 
Loring, D.H. and Rantala, R.T.T. (1992). Manual for the geochemical analyses of marine sediments and suspended particulate matter. Earth-Science Reviews, 32(4), 235283.

McLennan, S.M. and Murray, R.W. (1999). Geochemistry of sediments. In: Marshall, C.P., Fairbridge, R.W. (Eds.), Encyclopedia of Geochemistry. Kluwer Academic Publishers, Dordrecht, Germany, 282-292.

Metwally, M.E.S., Al-Muzaini, S., Jacob, P.G., Bahloul, M., Urushigawa, Y., Sato, S. and Matsmura, A. (1997). Petroleum hydrocarbons and related heavy metals in the near-shore marine sediments of Kuwait. Environment International, 3(1), 115-121.

Moore, J.W. (1991). Inorganic contaminants of surface water: research and monitoring priorities. Springer-Verlag, New York Inc. 334.

Murray, J.W., Top, Z. and Özsoy, E. (1991). Hydrographic properties and ventilation of the Black Sea. Deep-Sea Research, 38(Suppl.2A), S663-690.

Ramondetta, P.J. and Harris, W.H. (1976). Heavy metal distribution in Jamaica Bay sediments. Environmental Geology, 2, 145149.

Readman, J.W., Fillmann, G., Tolosa, I., Bartocci, J., Villeneuve, J.-P., Catinni, C. and Mee, L.D. (2002). Petroleum and PAH contamination of the Black Sea. Marine Pollution Bulletin, 44, 48-62.

Rehder, D. (2008). Bioinorganic Vanadium Chemistry (1st ed.). Hamburg, Germany: John Wiley and Sons, Ltd. 5, 9-10.

Romankevich, E.A. (1984). Geochemistry of organic matter in the ocean. Berlin, Heidelberg, New York: Springer and Verlag.

Ross, D.A. and Degens, E.T. (1974). Recent sediments of the Black Sea. In: Degens, E.T., Ross, D.A. (Eds.), The Black Sea Geology, Chemistry, and Biology, The American Association of Petroleum Geologists, Memoir 20, Tulsa, Oklahama, 183-189.

Sur, M., Sur, H.İ., Apak, R. and Erçağ, E. (2012). The pollution status of bottom surface sediments along the Turkish coast of the Black Sea. Turkish Journal of Fisheries and Aquatic Sciences, 12, 453-460.
Taylor, S.R. (1972). Abundance of chemical elements in the continental crust: a new table. Geochemica Cosmochim Acta, 28, 1273-1286.

Tomlison, M.J., Wang, J. and Caruso, J.A. (1994). Speciation of toxicologically important transition metals using ion chromatography with inductively coupled plasma mass spectrometric detection. Journal of Analytical Atmospheric Spectrometry, 9, 957-964.

Turekian, K. K. and Wedepohl, K.H. (1961). Distribution of the elements in some major units of the Earth's crust. Bulletin Geological Society of America, 72, 175192.

Ünlü, S. and Alpar, B. (2009). Hydrocarbon contamination in sediment offshore Yeşilırmak River, Black Sea, Turkey, In: E. Özhan (Ed.), Proceedings of the Ninth International Conference on the Mediterranean Coastal Environment, MEDCOAST 09, 2, 689-699.

Ünlü, S., Alpar, B. and Aydın, Ş. (2009). Spectrofluorometric characterization of aromatic hydrocarbon contamination in the sediment from the Zonguldak Industrial Region, Black Sea, Turkey. Fresenius Environmental Bulletin, 18, 474-480.

Varmuza, K. and Filzmoser, P. (2008). Introduction to multivariate statistical analysis in chemometrics. CRC Press, Taylor and Francis Group, Boca Raton, FL.

Wann, C. and Jiang, S. (1997). Determination of vanadium species in water samples by liquid chromatography-inductively coupled plasma mass spectrometry. Analytica Chimical Acta, 357 211-218.

Zaitsev Yu, Mamaev VO. (1997). Biological diversity in the Black Sea: A study of change and decline, Black Sea Environmental Series, Vol. 3, United Nations Publishing, New York, 208 pages. 